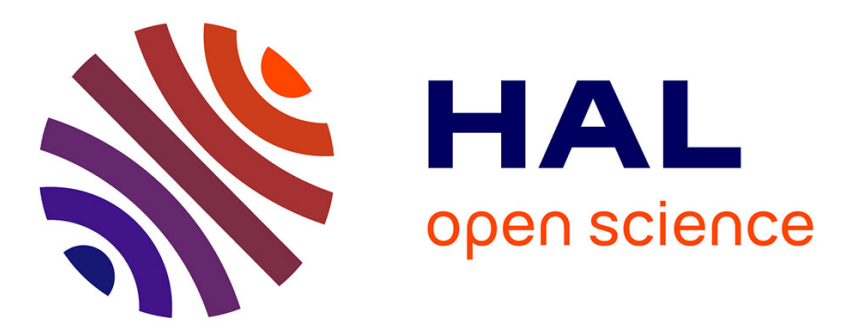

\title{
Study of TaN and TaN-Ta-TaN thin films as diffusion barriers in CeFe 4 Sb 12 skutterudite
}

\author{
L. Boulat, Romain Viennois, E. Oliviero, M. Dadras, N. Fréty
}

\section{To cite this version:}

L. Boulat, Romain Viennois, E. Oliviero, M. Dadras, N. Fréty. Study of TaN and TaN-Ta-TaN thin films as diffusion barriers in CeFe 4 Sb 12 skutterudite. Journal of Applied Physics, 2019, 126 (12), pp.125306. 10.1063/1.5105385 . hal-02338804

\section{HAL Id: hal-02338804 \\ https://hal.umontpellier.fr/hal-02338804}

Submitted on 30 Oct 2019

HAL is a multi-disciplinary open access archive for the deposit and dissemination of scientific research documents, whether they are published or not. The documents may come from teaching and research institutions in France or abroad, or from public or private research centers.
L'archive ouverte pluridisciplinaire HAL, est destinée au dépôt et à la diffusion de documents scientifiques de niveau recherche, publiés ou non, émanant des établissements d'enseignement et de recherche français ou étrangers, des laboratoires publics ou privés. 


\section{Study of TaN and TaN-Ta-TaN thin films as diffusion barriers in $\mathrm{CeFe}_{4} \mathrm{Sb}_{12}$ skutterudite}

Cite as: J. Appl. Phys. 126, 125306 (2019); https://doi.org/10.1063/1.5105385

Submitted: 27 April 2019 . Accepted: 06 September 2019 . Published Online: 26 September 2019

L. Boulat (D), R. Viennois (D), E. Oliviero (D), M. Dadras, and N. Fréty

\section{COLLECTIONS}

Paper published as part of the special topic on Advanced Thermoelectrics Note: This paper is part of the special topic on Advanced Thermoelectrics.
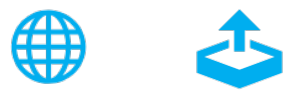

\section{ARTICLES YOU MAY BE INTERESTED IN}

Thermoelectric generator at optimal power with external and internal irreversibilities Journal of Applied Physics 126, 125111 (2019); https://doi.org/10.1063/1.5109464

Role of device architecture and $\mathrm{AlO}_{X}$ interlayer in organic Schottky diodes and their interpretation by analytical modeling

Journal of Applied Physics 126, 125501 (2019); https://doi.org/10.1063/1.5109083

Nonreciprocity and thermoelectric performance in a double-dot Aharonov-Bohm interferometer

Journal of Applied Physics 126, 124305 (2019); https://doi.org/10.1063/1.5111181

\section{Challenge us.} What are your needs for periodic signal detection?

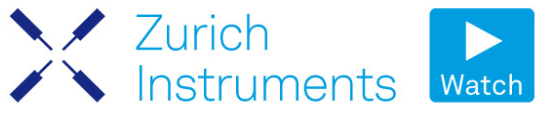

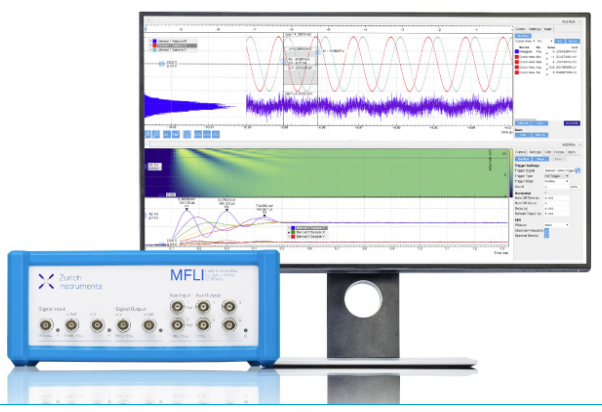




\title{
Study of TaN and TaN-Ta-TaN thin films as diffusion barriers in $\mathrm{CeFe}_{4} \mathrm{Sb}_{12}$ skutterudite
}

Cite as: J. Appl. Phys. 126, 125306 (2019); doi: 10.1063/1.5105385

Submitted: 27 April 2019 . Accepted: 6 September 2019.

Published Online: 26 September 2019

L. Boulat, ${ }^{1}$ (D) R. Viennois, ${ }^{1}$ (D) E. Oliviero, ${ }^{1}$ (D) M. Dadras, ${ }^{2}$ and N. Fréty ${ }^{1, a)}$

\author{
AFFILIATIONS \\ ${ }^{1}$ Institut Charles Gerhardt Montpellier, Université de Montpellier, CNRS, ENSCM 34095 Montpellier, France \\ ${ }^{2}$ Centre Suisse d'Electronique et de Microtechnique, 2002 Neuchâtel, Switzerland
}

Note: This paper is part of the special topic on Advanced Thermoelectrics.

a) Author to whom correspondence should be addressed: Nicole.Frety@umontpellier.fr

\begin{abstract}
The efficiency of thermoelectric devices depends on phase stability of layers constituting the device. TaN and TaN-Ta-TaN thin films, $900 \mathrm{~nm}$ thick, were investigated as diffusion barriers for the $\mathrm{CeFe}_{4} \mathrm{Sb}_{12}$ thermoelectric substrate in contact with the Cu electrode. It is shown that $\mathrm{Sb}$ diffuses through the TaN layer when the sample is heated above $400^{\circ} \mathrm{C}$. Multilayer TaN-Ta-TaN acts as the diffusion barrier for $\mathrm{Sb}$ and is efficient up to $500{ }^{\circ} \mathrm{C}$. When diffusion of $\mathrm{Sb}$ occurs above $400^{\circ} \mathrm{C}$ for $\mathrm{TaN}$ and above $500{ }^{\circ} \mathrm{C}$ for TaN-Ta-TaN, the formation of FeSb 2 and $\mathrm{Cu}_{2} \mathrm{Sb}$ precipitates was identified by XRD and TEM/energy dispersive $\mathrm{X}$-ray spectroscopy.
\end{abstract}

Published under license by AIP Publishing. https://doi.org/10.1063/1.5105385

\section{INTRODUCTION}

The conversion of missed heat generated during industrial processes into electricity based on thermoelectricity is of particular interest and is becoming more and more crucial in the current environmental context. ${ }^{1,2}$ Direct conversion of thermal energy into electrical energy requires the use of thermoelectric (TE) modules. These modules are composed of TE material pairs which are connected in series, electrically and in parallel, thermally. Each couple is made of two legs of $\mathrm{n}$ - and $\mathrm{p}$-type semiconductors. Applying a temperature gradient results in the carriers' mobility from the hot to the cold sides and the generation of a voltage through the Seebeck effect. The efficiency of the TE module is dependent on the $\mathrm{TE}$ properties of the leg materials which are determined from the value of the figure of merit, $\mathrm{Z}\left(\mathrm{Z}=\alpha^{2} \sigma / \kappa\right.$, where $\alpha$ is the Seebeck coefficient, $\sigma$ the electrical conductivity, and $\kappa$ the thermal conductivity), and more commonly by the dimensionless figure of merit, ZT (where $\mathrm{T}$ is the temperature). ${ }^{3}$ Skutterudite compounds have been reported to be promising TE materials for applications in the medium temperature range from 400 to $600{ }^{\circ} \mathrm{C}^{4-6}$ Doped or filled $\mathrm{CoSb}_{3}$ and $\mathrm{CeFe}_{4} \mathrm{Sb}_{12}$-based skutterudites have been shown to be good candidates for $\mathrm{n}$ - and p-type legs of TE devices, respectively. $^{7-11} \mathrm{ZT}$ values as high as 0.85 were obtained for $\mathrm{CeFe}_{4} \mathrm{Sb}_{12}$ and $\mathrm{CoSb}_{3}$ compounds at about $400{ }^{\circ} \mathrm{C}$ and as high as
1.9 for doped skutterudites at $550{ }^{\circ} \mathrm{C} .{ }^{6,12-18}$ However, the performance of TE devices is strongly dependent on the connection and adherence between TE legs with metal electrodes and on the quality of the interface. ${ }^{19-22}$ This is one of the key issues, particularly for the hot-side TE material/metal electrode joint. Maintaining at high temperature can influence the performance of the device drastically by elemental interdiffusion and interfacial reactions which raise the interface electrical resistivity and decrease its mechanical properties. ${ }^{22,23}$

Consequently, a diffusion barrier layer is required to avoid any interfacial reaction between the thermoelectric substrate and the hot-side electrode. ${ }^{19}$ Investigations have been carried out to develop joining of $\mathrm{CoSb}_{3}$-based skutterudite couples with metal electrodes. ${ }^{24-30}$ Fan et al. ${ }^{24}$ studied the effectiveness of a Ti foil in joining a $\mathrm{CoSb}_{3}$ substrate to a Mo electrode by spark plasma sintering at $580^{\circ} \mathrm{C}$ under a pressure of $40 \mathrm{MPa}$ in vacuum. They observed the formation of an intermediate TiSb layer at the $\mathrm{CoSb}_{3} / \mathrm{Ti}$ boundary and of a Ti-Mo solid solution layer with graded composition at the $\mathrm{Ti} / \mathrm{Mo}$ interface. They assumed that this Ti-Mo graded layer may contribute to the bonding between $\mathrm{Ti}$ and $\mathrm{Mo}$ and that the interfacial resistance in the $\mathrm{CoSb}_{3} / \mathrm{Ti} / \mathrm{Mo}$ is minimized. They showed that the thickness and the composition of the intermediate layer remained unchanged after annealing at $500^{\circ} \mathrm{C}$ during $1000 \mathrm{~h}$ under vacuum. Zhao et al..$^{25-26}$ investigated the interfacial reactions 
in $\mathrm{CoSb}_{3} / \mathrm{Ti} / \mathrm{Mo}-\mathrm{Cu}$ joints after thermal aging in the $500-600^{\circ} \mathrm{C}$ temperature range from 0 to 30 days in vacuum. They showed the formation of an intermetallic compound layer composed of $\mathrm{TiCoSb}, \mathrm{TiSb}_{2}$, and TiSb at the interface. The thickness of this layer increases with aging due to the diffusion of $\mathrm{Ti}$ and $\mathrm{Sb}$. This results in a decrease of the shear strength with the formation of cracks at the interface. Chen et al. ${ }^{29}$ studied the interfacial reactions in $\mathrm{Ni} /$ $\mathrm{CoSb}_{3}$ couples after annealing at $450{ }^{\circ} \mathrm{C}$ during $2-24 \mathrm{~h}$. They observed interfacial reactions with the formation of $\mathrm{Ni}_{5} \mathrm{Sb}_{2} /(\mathrm{Co}, \mathrm{Ni})$ $\mathrm{Sb}$ interlayers. Chen et al. ${ }^{30}$ investigated $\mathrm{Co}, \mathrm{Ni}$, and Ti materials as potential barrier layers for $\mathrm{CoSb}_{3} / \mathrm{Ag}-\mathrm{Cu}$ couples at 450 and $600{ }^{\circ} \mathrm{C}$ for 1-44 days in vacuum. They observed interfacial reactions at both temperatures even if they are reduced with the introduction of barrier layers. They reported the formation of $\mathrm{CoSb}_{2}$ and $\mathrm{CoSb}$, $\mathrm{Ni}_{5} \mathrm{Sb}_{2}$ and $(\mathrm{Co}, \mathrm{Ni}) \mathrm{Sb}$, and $\mathrm{TiSb}, \mathrm{TiSb}_{2}$ and $\mathrm{TiCoSb}$ phases for $\mathrm{Co}$, $\mathrm{Ni}$, and Ti barriers. They concluded that $\mathrm{Co}$ is a good barrier at $450{ }^{\circ} \mathrm{C}$ with a good adhesion to both $\mathrm{CoSb}_{3}$ and $\mathrm{Ag}-\mathrm{Cu}$ and relatively low interfacial reaction rates.

While diffusion barriers have been largely investigated for n-type $\mathrm{CoSb}_{3}$ skutterudites, only few results were reported for the p-type skutterudite, $\mathrm{Ce}_{\mathrm{y}} \mathrm{Fe}_{\mathrm{x}} \mathrm{Co}_{4-\mathrm{x}} \mathrm{Sb}_{12}$, which is the most promising family. ${ }^{31-34} \mathrm{Gu}$ et al. ${ }^{34}$ studied the interfacial stability of the p-type $\mathrm{Ti} / \mathrm{Ce}_{\mathrm{y}} \mathrm{Fe}_{\mathrm{x}} \mathrm{Co}_{4-\mathrm{x}} \mathrm{Sb}_{12}$ joints in comparison with the n-type $\mathrm{Ti} / \mathrm{Yb}_{0.6} \mathrm{Co}_{4} \mathrm{Sb}_{12}$ after aging in vacuum at $550{ }^{\circ} \mathrm{C}$ from 1 to 30 days. They showed that interdiffusion results in the formation of intermetallic compound layers at the interface. The formation of a trilayer (TiCoSb, $\mathrm{TiSb}_{2}, \mathrm{TiSb}$ ) is observed in the n-type joint, whereas a bilayer $\left(\mathrm{TiSb}_{2}, \mathrm{Ti}-\mathrm{Sb}\right)$ is observed for the p-type one. Moreover, the growth rate of the interfacial layers in the p-type skutterudite joint is lower than in the n-type one. The authors concluded that Ce filling and Fe doping slow down the decomposition of the p-type joint and that $\mathrm{Ti}$ is a promising barrier layer material for the p-type $\mathrm{Ce}_{\mathrm{y}} \mathrm{Fe}_{\mathrm{x}} \mathrm{Co}_{4-\mathrm{x}} \mathrm{Sb}_{12}$ skutterudite.

Previous studies ${ }^{35,36}$ reported the interest in using TaN against $\mathrm{Cu}$ diffusion for microelectronics where $\mathrm{TaN}$ was selected due to its high thermal stability and electrical conductivity. ${ }^{37,38}$ More recently, Hsu et al. ${ }^{39,40}$ showed that $\mathrm{TaN}$ is a good diffusion barrier for thermoelectric applications up to $200^{\circ} \mathrm{C}$. In a previous work, we studied the efficiency of a TaN interlayer in $\mathrm{CeFe}_{4} \mathrm{Sb}_{12} / \mathrm{Cu}$ after aging at $600{ }^{\circ} \mathrm{C}$. ${ }^{41}$ It was found that $\mathrm{CeFe}_{4} \mathrm{Sb}_{12}$ and $\mathrm{Cu}$ chemically react and form $\mathrm{CeCu}_{2}$ and $\mathrm{Cu}_{2} \mathrm{Sb}$ phases. Using $1.5 \mu \mathrm{m}$ thick TaN thin film as the diffusion barrier showed its efficiency against $\mathrm{Ce}$ diffusion but does not inhibit $\mathrm{Sb}$ diffusion from the skutterudite substrate to the copper surface film. The formation of a $\mathrm{Cu}_{2} \mathrm{Sb}$ phase indicates that interfacial reactions induce the decomposition of the skutterudite material and the decrease of the figure of merit.

The current paper focuses on the thermal stability and efficiency of a multilayer, TaN-Ta-TaN, as a diffusion barrier for $\mathrm{CeFe}_{4} \mathrm{Sb}_{12} / \mathrm{Cu}$ in comparison with single TaN layer in the temperature range $400-600^{\circ} \mathrm{C}$.

\section{MATERIAL AND METHODS}

$\mathrm{CeFe}_{4} \mathrm{Sb}_{12}$ skutterudite ingots were synthesized by direct reaction of stoichiometric amounts of $\mathrm{Ce}, \mathrm{Fe}$, and $\mathrm{Sb}$ elements as previously described. ${ }^{42,43} \mathrm{CeFe}_{4} \mathrm{Sb}_{12}$ ingots were cut into $3 \mathrm{~mm}$ thick pieces followed by mechanical polishing and then ultrasonic cleaning in ethanol. The TaN $900 \mathrm{~nm}$ thick single layer and TaN-Ta-TaN, each $300 \mathrm{~nm}$, multilayer thin films were deposited onto the skutterudite substrate by radio frequency (RF) sputtering as reported in previous papers. ${ }^{44,45} \mathrm{~A} \mathrm{Cu}$ layer, about $1 \mu \mathrm{m}$ thick, was subsequently sputtered on these barriers. The stability of the multilayer barrier in comparison to the single barrier was investigated after $6 \mathrm{~h}$ annealing under vacuum $\left(3 \cdot 10^{-4} \mathrm{~Pa}\right)$ in the temperature range of $400-600^{\circ} \mathrm{C}$. The interfacial reactions and the phase formation were studied using X-ray diffraction (XRD) and transmission electron microscopy (TEM) associated to energy dispersive $\mathrm{X}$-ray spectroscopy (EDS). A $\theta-2 \theta$ diffractometer (Philips Xpert Pro MRD) with a $\mathrm{Cu}$ target $\mathrm{X}$-ray tube working at $40 \mathrm{kV}$ and $25 \mathrm{~mA}$ was used for crystallography and phase analysis. The microstructure observations were performed using a JEOL 2200FS microscope (MEA Platform, Université de Montpellier). The microscope was operated at an accelerating voltage of $200 \mathrm{kV}$. STEM-EDS analyses were obtained with a spot size of $0.7 \mathrm{~nm}$ and with acquisition times from 200 to $740 \mathrm{~s}$ on an Oxford Instrument X-Max ${ }^{\mathrm{N}} 100$ TLE EDX detector. TEM specimens were thinned in cross section using the focused ion beam (FIB) technique with a Ga ion beam and attached to the molybdenum sample holder.

\section{RESULTS AND DISCUSSION}

TEM observations of the $\mathrm{CeFe}_{4} \mathrm{Sb}_{12} /$ barrier/Cu are reported in Fig. 1. The as-deposited TaN and TaN-Ta-TaN films present a columnar growth perpendicular to the substrate surface. This columnar growth is commonly observed in sputtered films considering the process parameters used as predicted by the model of Movchan and Demchishin ${ }^{46}$ extended by Thornton. ${ }^{47}$ The columnar grain structure with intercolumn voids and density-deficient grain boundaries is characteristic of sputtered films. ${ }^{48}$ The mean grain size of 4 and $6 \mathrm{~nm}$ was determined from X-ray diffraction analyses, respectively, for $\mathrm{Ta}$ and $\mathrm{TaN}$ layers using the Scherrer formula. ${ }^{49}$

\section{A. Study of the TaN single layer barrier}

The role of the single TaN layer in elemental interdiffusion was investigated first. Figure 2(i) shows the XRD patterns of the

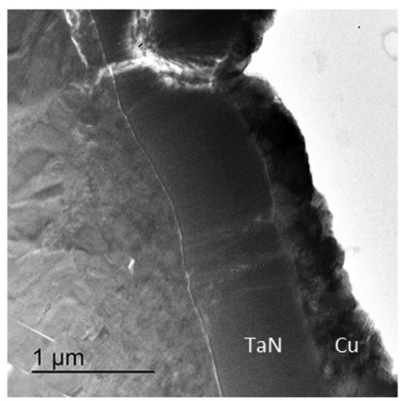

a)

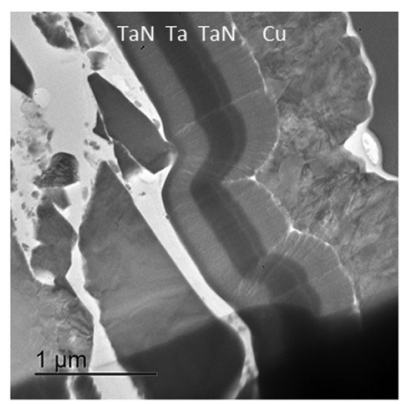

b)
FIG. 1. TEM cross section of (a) $\mathrm{CeFe}_{4} \mathrm{Sb}_{12} / \mathrm{TaN} / \mathrm{Cu}$ and (b) $\mathrm{CeFe}_{4} \mathrm{Sb}_{12} /$ TaN-Ta-TaN/Cu. 


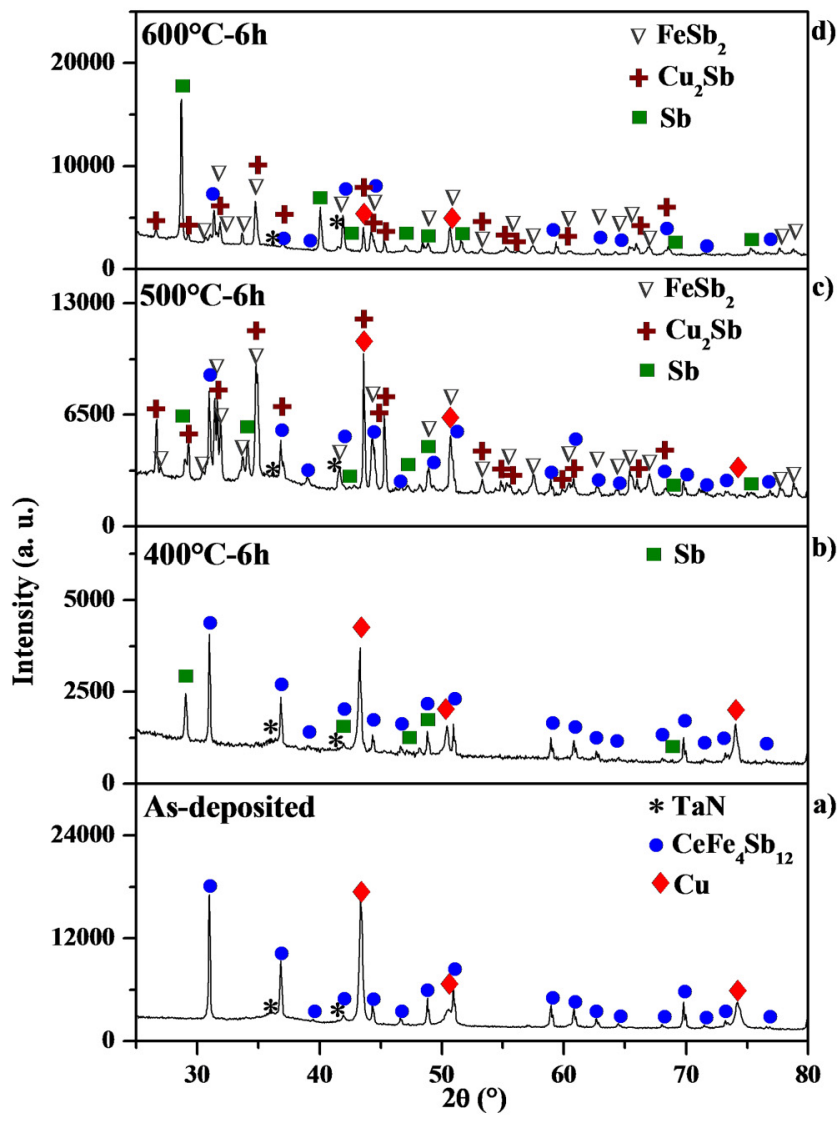

i)

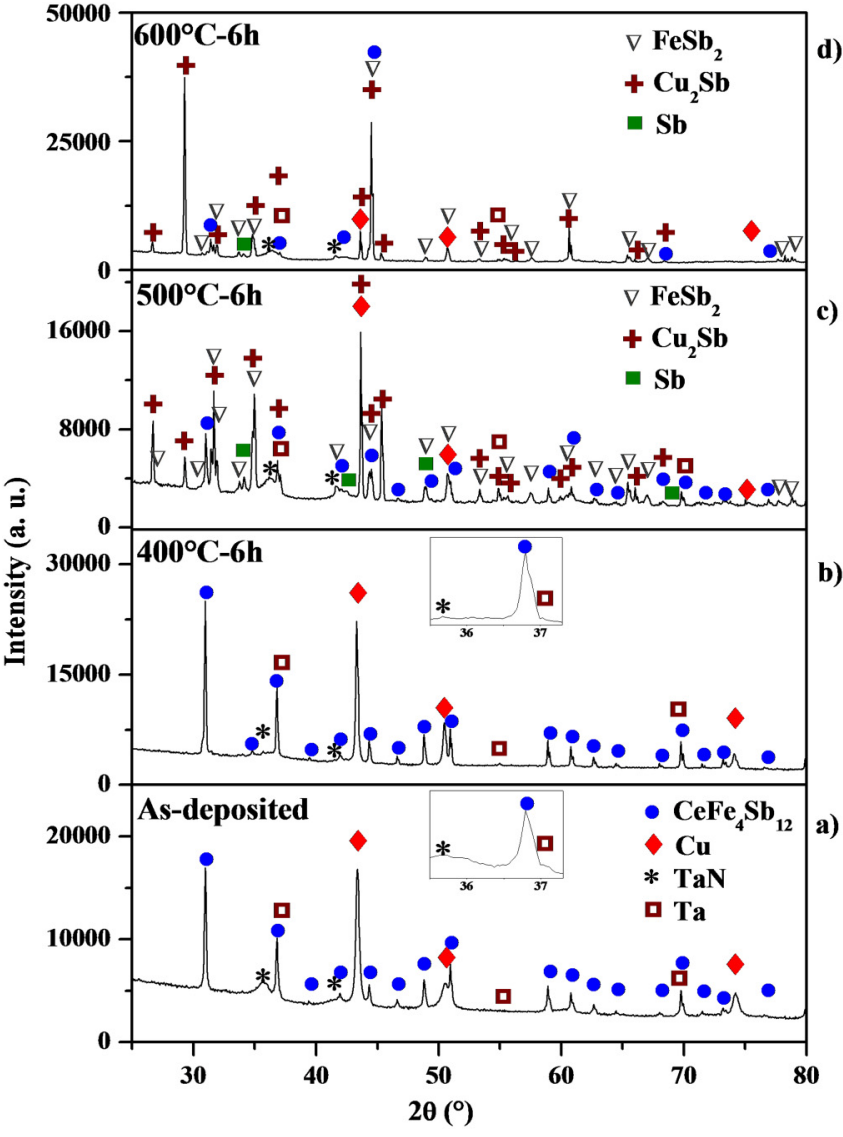

ii)

FIG. 2. XRD patterns of (i) $\mathrm{CeFe}_{4} \mathrm{Sb}_{12} / \mathrm{TaN} / \mathrm{Cu}$ and (ii) $\mathrm{CeFe}_{4} \mathrm{Sb}_{12} / \mathrm{TaN}$-Ta-TaN/Cu (a) as-deposited and after $6 \mathrm{~h}$ vacuum annealing at (b) $400{ }^{\circ} \mathrm{C}$, (c) $500{ }^{\circ} \mathrm{C}$, and (d) $600^{\circ} \mathrm{C}$.

$\mathrm{CeFe}_{4} \mathrm{Sb}_{12} / \mathrm{TaN} / \mathrm{Cu}$ sample in the as-deposited state and after annealing. In the as-deposited state, the characteristic peaks of $\mathrm{CeFe}_{4} \mathrm{Sb}_{12}, \mathrm{TaN}$, and $\mathrm{Cu}$ phases are observed. The filled $\mathrm{CeFe}_{4} \mathrm{Sb}_{12}$ phase crystallizes in the cubic structure of the Im-3 space group, where $\mathrm{Fe}$ atoms are located at the center of distorted octahedral formed by $\mathrm{Sb}$ and $\mathrm{Ce}$ atoms. ${ }^{50}$ The tantalum nitride thin film is observed to be the $\delta$-TaN phase with an NaCl-type structure and the copper film crystallizes in the polycrystalline fcc- $\mathrm{Cu}$ phase. ${ }^{44}$

After annealing at $400{ }^{\circ} \mathrm{C}$, the presence of the $\mathrm{Sb}$ phase was confirmed by XRD and TEM investigation (Fig. 3). This new Sb phase is formed in the $\mathrm{Cu}$ layer. The formation of Sb-rich phases in $\mathrm{Cu}$ confirms diffusion of this element through the columnar $\mathrm{TaN}$ layer to the $\mathrm{Cu}$ layer. $\mathrm{Sb}$ is well known as very mobile specie depending on temperature. ${ }^{50,51} \mathrm{Cu}_{2} \mathrm{Sb}$ and $\mathrm{FeSb}_{2}$ phases are formed after annealing in the $500-600{ }^{\circ} \mathrm{C}$ temperature range [Fig. 2(i)]. The $\mathrm{Cu}_{2} \mathrm{Sb}$ phase results from the diffusion of $\mathrm{Sb}$ and the reaction with $\mathrm{Cu}$. Parallel to this, depletion in $\mathrm{Sb}$ of $\mathrm{CeFe}_{4} \mathrm{Sb}_{12}$ produces a partial decomposition of the skutterudite and the formation of $\mathrm{FeSb}_{2}$.
These results point out that a TaN single layer, $900 \mathrm{~nm}$ thick, does not appear to be effective against $\mathrm{Sb}$ diffusion for the temperature above $400{ }^{\circ} \mathrm{C}$. However, this single layer limits Ce diffusion, inhibiting the subsequent formation of the $\mathrm{Cu}_{2} \mathrm{Sb}$ and $\mathrm{CeCu}_{2}$ intermetallic phases.

\section{B. Study of the TaN-Ta-TaN multilayer barrier}

The presence of characteristic peaks of $\mathrm{Ta}, \mathrm{TaN}, \mathrm{Cu}$ and $\mathrm{CeFe}_{4} \mathrm{Sb}_{12}$ is remarked in as deposited TaN-Ta-TaN multilayer films [Fig. 2(ii)]. After annealing at $400{ }^{\circ} \mathrm{C}$ for $6 \mathrm{~h}$, the XRD pattern does not show the presence of the $\mathrm{Sb}$ phase as previously observed in the case of the TaN single layer barrier. These results are confirmed also by TEM observations which do not show the presence of any new phase in the $\mathrm{Cu}$ substrate and by the $\mathrm{Sb}$ concentration profile (Fig. 4). Figure 5 shows the EDS mapping of $\mathrm{Sb}$ and $\mathrm{Cu}$ elements for the single and multilayer barriers. These elemental images show the presence of $\mathrm{Sb}$ in the $\mathrm{Cu}$ layer in the case of the sample with the TaN monolayer after 


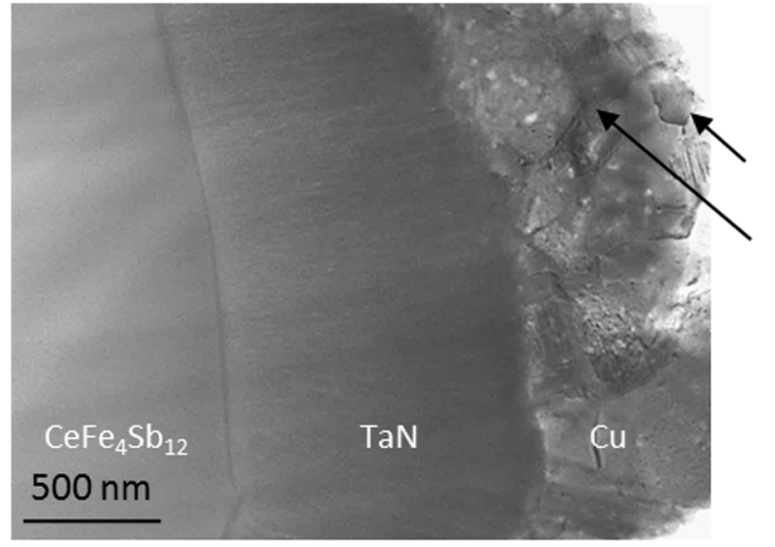

a)
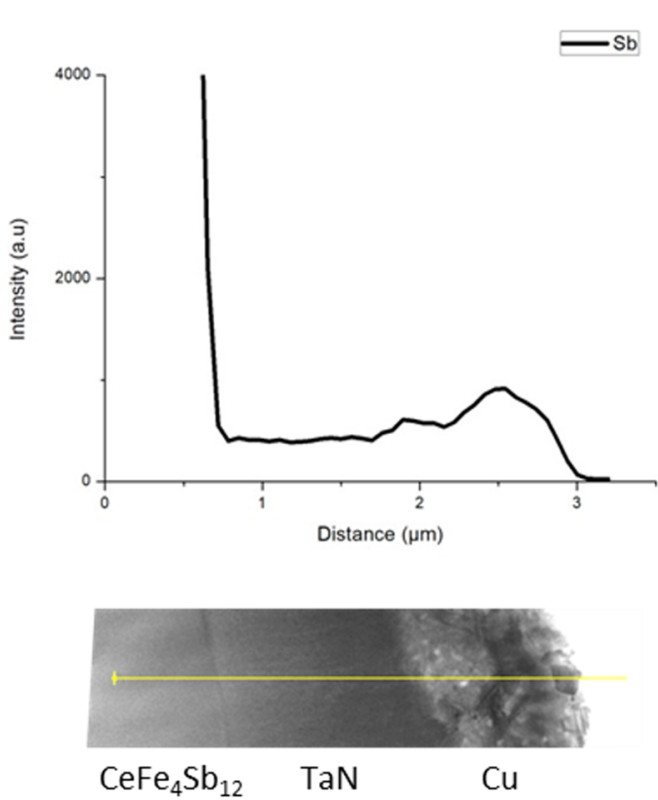

b)

FIG. 3. (a) Cross section STEM micrograph of $\mathrm{CeFe}_{4} \mathrm{Sb}_{12} / \mathrm{TaN} / \mathrm{Cu}$ and (b) Sb EDS profile after $6 \mathrm{~h}$ annealing at $400{ }^{\circ} \mathrm{C}$ (arrows: Sb-rich phases).

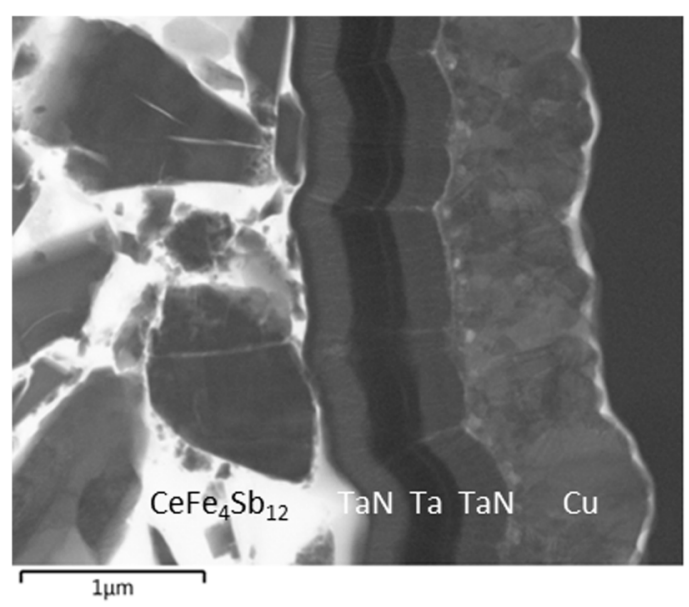

a)
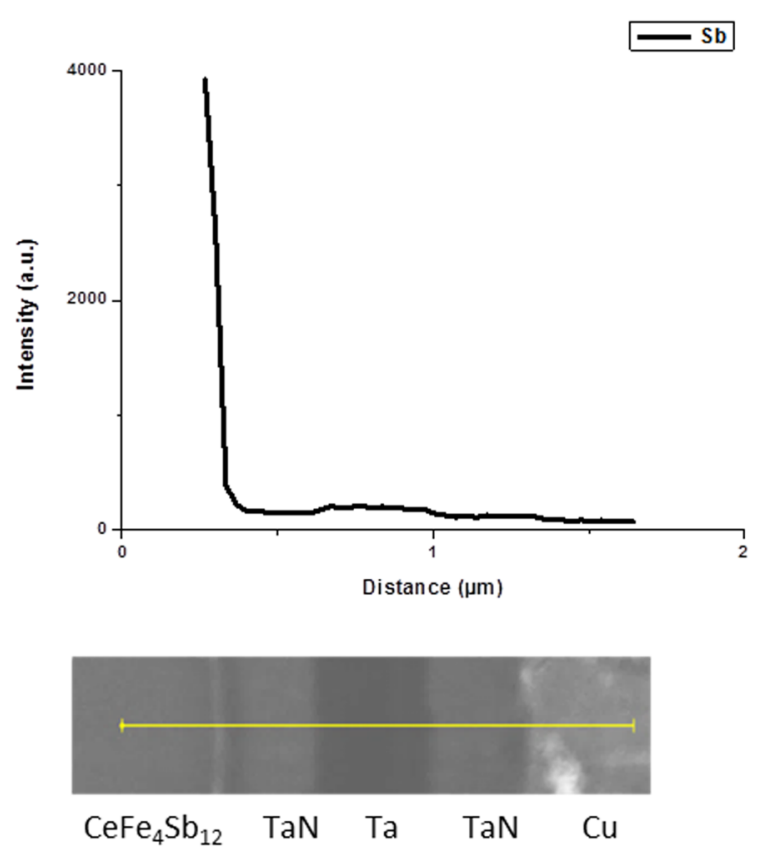

b)

FIG. 4. (a) Cross section STEM micrograph of $\mathrm{CeFe}_{4} \mathrm{Sb}_{12} / \mathrm{TaN}-\mathrm{Ta}-\mathrm{TaN} / \mathrm{Cu}$ and (b) $\mathrm{Sb}$ EDS profile after $6 \mathrm{~h}$ annealing at $400^{\circ} \mathrm{C}$. 
a)

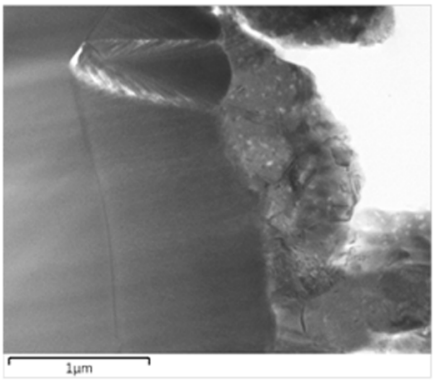

$\operatorname{Sb}\left(\mathbf{L}_{\alpha_{1}}\right)$

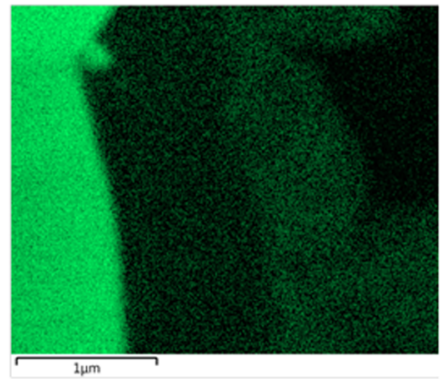

b)
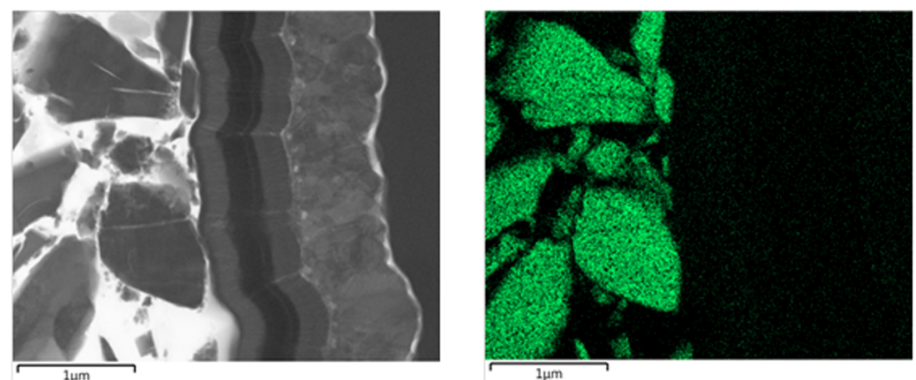

$\mathrm{Cu}\left(\mathrm{L}_{\alpha_{1-2}}\right)$
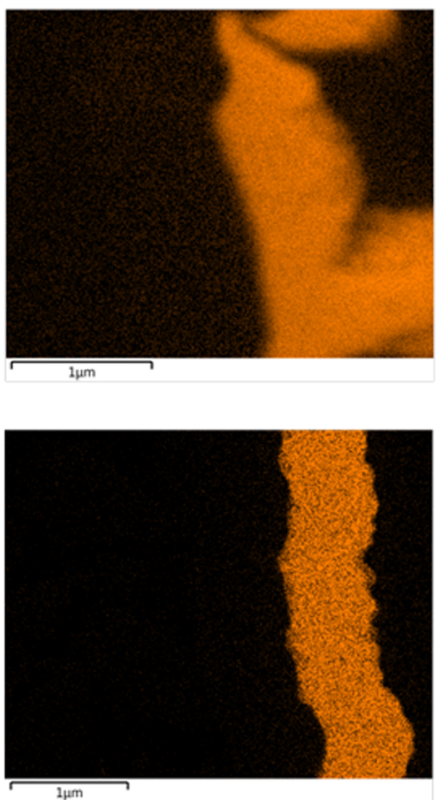

FIG. 5. STEM-EDS mapping of $\mathrm{Sb}\left(\mathrm{L}_{\alpha 1}\right)$ and $\mathrm{Cu}\left(\mathrm{L}_{\alpha 1-2}\right)$ after $6 \mathrm{~h}$ annealing at $400{ }^{\circ} \mathrm{C}$ (a) $\mathrm{CeFe}_{4} \mathrm{Sb}_{12} / \mathrm{TaN} / \mathrm{Cu}$ and (b) $\mathrm{CeFe}_{4} \mathrm{Sb}_{12} / \mathrm{TaN}-\mathrm{Ta}-\mathrm{TaN} / \mathrm{Cu}$.

treatment at $400^{\circ} \mathrm{C}$ for $6 \mathrm{~h}$ and confirm the diffusion of this element through $\mathrm{TaN}$. On the other hand, no $\mathrm{Sb}$ is found in the case of sample with the TaN-Ta-TaN multilayer after a treatment of $400{ }^{\circ} \mathrm{C}$ for $6 \mathrm{~h}$, which put in evidence the effectiveness of the chosen multilayer structure. However, the XRD spectra showed the formation of the secondary phases, $\mathrm{Cu}_{2} \mathrm{Sb}$ and $\mathrm{FeSb}_{2}$, in the multilayer sample above $500{ }^{\circ} \mathrm{C}$ as observed also for the monolayer sample.

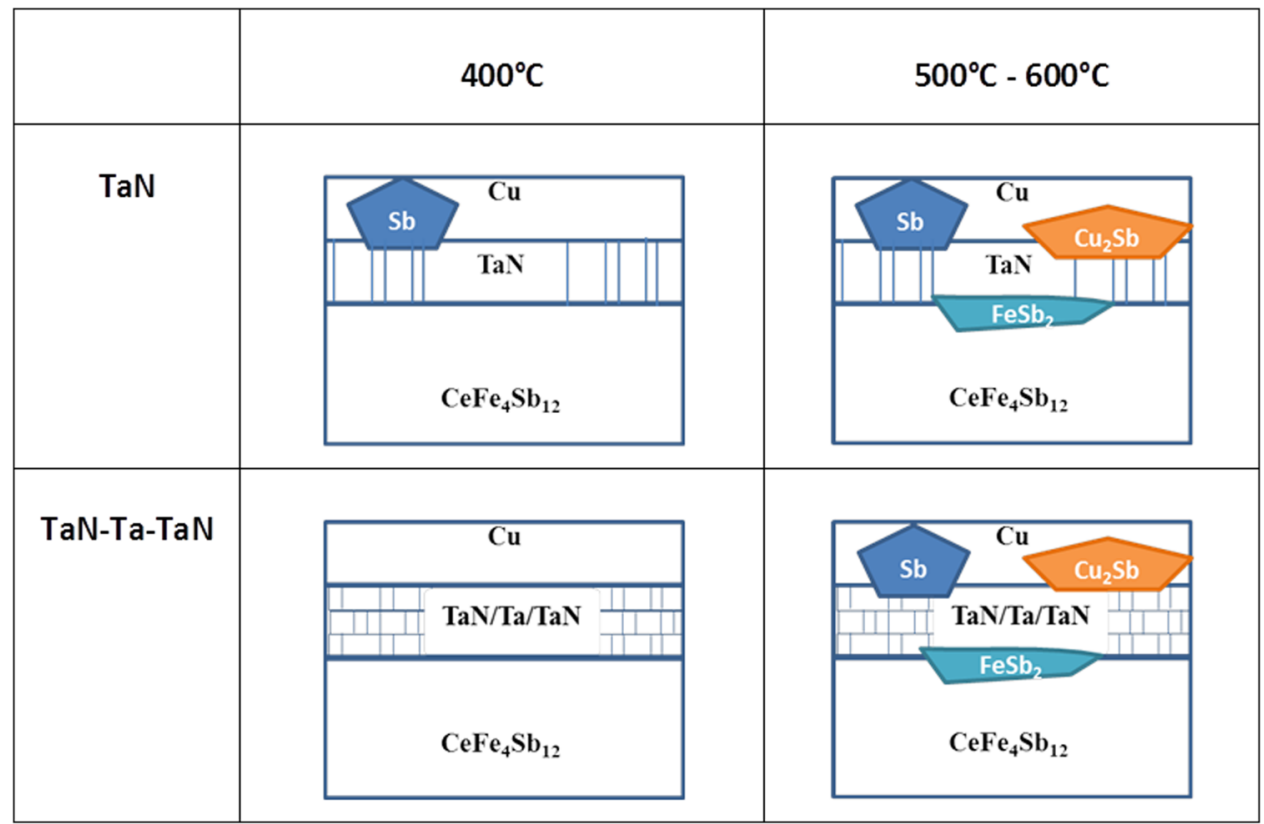

FIG. 6. Schematic illustration of single and multilayer barrier samples cross sections after annealing at $400^{\circ} \mathrm{C}$ and 500 to $600^{\circ} \mathrm{C}$. 


\section{Discussion: TaN-Ta-TaN multilayer vs TaN single layer barriers}

The efficiency of the multilayer barrier in comparison with the single layer barrier is schematically reported in Fig. 6. At $400{ }^{\circ} \mathrm{C}$, the performance of the TaN-Ta-TaN multilayer is evidenced as the $\mathrm{Sb}$ phase formation is not observed in the $\mathrm{Cu}$ layer. In the case of the single $\mathrm{TaN}$ layer, the $\mathrm{Sb}$ diffused to the $\mathrm{Cu}$ layer and formed $\mathrm{Cu}_{2} \mathrm{Sb}$ precipitates, which suggests in parallel a chemical decomposition of the skutterudite. The efficiency of TaN single layers vs TaN-Ta-TaN multilayers as diffusion barriers in the CMOS technology process was investigated previously, where copper is used for electrical interconnection. ${ }^{52}$ It has been reported that the efficiency of the TaN thin film as the diffusion barrier depends on its microstructure. ${ }^{5,7,53}$ In the reactive sputtering process, TaN layers are grown with a characteristic columnar structure perpendicular to the substrate, associated with intercolumn voids. ${ }^{54,55}$ The diffusion mechanism may be assumed to be simultaneously governed by the copper migration through the $\mathrm{TaN}$-intercolumn voids and grain boundaries. In our previous study, we showed that a $\mathrm{TaN} / \mathrm{Ta} / \mathrm{TaN}$ multilayer is more efficient against copper diffusion than a TaN single layer. ${ }^{52}$ The copper diffusion is stopped at the $\mathrm{Ta} / \mathrm{TaN}$ interface, where a discontinuity in the columnar growth is observed. In the present study, we show that the critical point is the diffusion of $\mathrm{Sb}$ from the skutterudite material to the copper surface layer. The formation of Sb-rich phases in the copper layer is observed when a TaN single layer is used as a diffusion barrier. In the case of the TaN-Ta-TaN multilayer barrier, Sb diffusion is not observed and seems to be impeded by the multilayer stacking. Based on our previous study, the Sb diffusion mechanism may be assumed to be mainly governed by its migration through the TaNintercolumn voids. The multilayer structure promotes the barrier efficiency that is assumed to be due to the discontinuity of the columnar growth and the creation of additional layer interfaces. These results are supported by $\mathrm{Sb}$ concentration profiles and mappings which are clear evidence for the higher efficiency of the multilayer barrier.

At temperatures higher than $500{ }^{\circ} \mathrm{C}$, the $\mathrm{Sb}$ diffusion is not prevented neither by the single layer nor the multilayer barriers, which results in the formation of $\mathrm{FeSb}_{2}$ and $\mathrm{Cu}_{2} \mathrm{Sb}$ precipitates. Degradation of the thermoelectric properties of the skutterudite and of the skutterudite/copper electrical contact is, therefore, expected.

\section{CONCLUSION}

The efficiency of TaN single layer and TaN-Ta-TaN multilayer diffusion barriers in $\mathrm{CeFe}_{4} \mathrm{Sb}_{12} / \mathrm{Cu}$ joining has been studied after annealing at $400{ }^{\circ} \mathrm{C}$ and $500-600^{\circ} \mathrm{C}$ for $6 \mathrm{~h}$ in secondary vacuum. Regarding the single TaN layer, $\mathrm{Sb}$ diffusion from the skutterudite substrate to the copper layer is observed at $400{ }^{\circ} \mathrm{C}$. Further elemental diffusion is evidenced for higher temperatures, from 500 to $600{ }^{\circ} \mathrm{C}$, with the additional formation of $\mathrm{FeSb}_{2}$ and $\mathrm{Cu}_{2} \mathrm{Sb}$ precipitates. For the TaN-Ta-TaN barrier, the microstructural study shows a similar behavior as for the TaN barrier in the $500-600^{\circ} \mathrm{C}$ temperature range. However, this multilayer structure is interestingly an efficient diffusion barrier for the temperature below $500^{\circ} \mathrm{C}$. The diffusion of $\mathrm{Sb}$ to the $\mathrm{Cu}$ surface layer is then inhibited which points out the role of sublayer interfaces in the diffusion mechanisms.

\section{ACKNOWLEDGMENTS}

This work was partly supported by the PHC-Germaine de Staël program and the French Renater network. D. Troadec, IEMN Lille, is greatly acknowledged for the FIB sample preparation. D. Ravot is also greatly acknowledged for the fruitful discussion.

\section{REFERENCES}

${ }^{1}$ F. J. DiSalvo, Science 285, 703 (1999).

${ }^{2}$ D. M. Rowe, Renew. Energy 16, 1251 (1999).

${ }^{3}$ C. M. Bhandari and D. M. Rowe, CRC Handbook of Thermoelectrics (CRC Press, 1995), Vol. 5, p. 43.

${ }^{4}$ B. C. Sales, Handbook on the Physics and Chemistry of Rare Earths (North Holland Elsevier, 2003), Vol. 33, p. 34.

${ }^{\mathbf{5}}$ J. R. Sootsman, D. Y. Chung, and M. G. Kanatzidis, Angew. Chem. Int. Ed. 48, 8616 (2009).

${ }^{6}$ P. F. Qiu, J. Yang, R. H. Liu, X. Shi, X. Y. Huang, G. J. Snyder, W. Zhang, and L. D. Chen, J. Appl. Phys. 109, 063713 (2011).

${ }^{7}$ H. Kitagawa, M. Hasaka, T. Morimura, H. Nakashima, and S. Kondo, Mater. Res. Bull. 35, 185 (2000).

${ }^{8}$ G. Rogl, A. Grytsiv, P. Heinrich, E. Bauer, P. Kumar, N. Peranio, O. Eibl, J. Horky, M. Zehetbauer, and P. Rogl, Acta Mater. 91, 227 (2015).

${ }^{9}$ L. Chapon, D. Ravot, and J. C. Tedenac, J. Alloys Compd. 282, 58 (1999).

${ }^{10}$ T. Morimura and M. Hasaka, Scr. Mater. 48, 495 (2003).

${ }^{11}$ A. Kaltzoglou, P. Vaqueiro, K. S. Knight, and A. V. Powell, J. Solid State Chem. 193, 36 (2012).

${ }^{12}$ X. Shi, J. Yang, J. R. Salvador, M. Chi, J. Y. Cho, H. Wang, S. Bai, J. Yang, W. Zhang, and L. Chen, J. Am. Chem. Soc. 133, 7837 (2011).

${ }^{13}$ M. El-Genk, H. Saber, and T. Caillat, J. Energy Convers. Manage. 44(11), 1755 (2003).

${ }^{14}$ G. S. Nolas, M. Kaeser, R. T. Littleton, and T. M. Tritt, App. Phys. Lett. 77, 1855 (2000).

${ }^{15}$ G. Rogl, A. Grytsiv, P. Rogl, N. Peranio, E. Bauer, M. Zehetbauer, and O. Eibl, Acta Mater. 63, 30 (2014)

${ }^{16}$ B. C. Sales, B. C. Chakoumakos, and V. Keppens, Phys. Rev. B 56, 15081 (1997).

${ }^{17}$ G. Rogl, A. Grytsiv, K. Yubuta, S. Puchegger, E. Bauer, C. Raju, R. C. Mallik, P. Rogl et al., Acta Mater. 95, 201 (2015).

${ }^{18}$ U. Khan, K. Kobayashi, D.-M. Tang, Y. Yamauchi, K. Hasegawa, M. Mitome, Y. Xue, B. Jiang, K. Tsuchiya, D. Golberg, Y. Bando, and T. Mori, Nano. Energy 31, 152 (2017).

${ }^{19}$ K. T. Wojciechowski, R. Zybala, and R. Mania, Microelectron. Reliab. 51, 1198 (2011).

${ }^{20}$ D. Zhao, H. Geng, and X. Teng, J. Alloys Compd. 517, 198 (2012).

${ }^{21}$ S. E. Dutton, S. Skinner, and G. J. Snyder, "Interfaces in energy mater," APL Mater. 7, 012901 (2019).

${ }^{22}$ M.S. El-Genk, H.H. Saber, in Proceedings of the 21st International Conference on Thermoelectrics (IEEE, 2002), p. 408.

${ }^{23}$ K. Kaszyca, M. Schmidt, M. Chmielewski, K. Pietrzak, and R. Zybala, Mater. Today Proc. 5, 10277 (2018).

${ }^{24}$ J. Fan, L. Chen, S. Bai, and X. Shi, Mater. Lett. 58, 3876 (2004).

${ }^{25}$ D. Zhao, X. Li, L. He, W. Jiang, and L. Chen, Intermet. 17, 136 (2009).

${ }^{26}$ D. Zhao, X. Li, L. He, W. Jiang, and L. Chen, J. Alloys Compd. 477, 425 (2009).

${ }^{27}$ B. Song, S. Lee, S. Cho, M.-J. Song, S.-M. Choi, W.-S. Seo, Y. Yoon, and W. Lee, J. Alloys Compd. 617, 160 (2014).

${ }^{28} \mathrm{M}$. Gu, X. Xia, X. Li, X. Huang, and L. Chen, J. Alloys Compd. 610, 665 (2014). 
${ }^{29}$ W.-A. Chen, S.-W. Chen, S.-M. Tseng, H.-W. Hsiao, Y.-Y. Chen, G. J. Snyder, and Y. Tang, J. Alloys Compd. 632, 500 (2015).

${ }^{30}$ S. W. Chen, A. H. Chu, and D. S.-H. Wong, J. Alloys Compd. 699, 448 (2017).

${ }^{31}$ X. Tang, L. Chen, T. Goto, and T. Hirai, J. Mater. Res. 16(3), 837 (2001).

${ }^{32}$ Q. Jie, H. Wang, W. Liu, H. Wang, G. Chen, and Z. Ren, Phys. Chem. Chem. Phys. 15, 6809 (2013).

${ }^{33}$ G. Tan, W. Liu, S. Wang, Y. Yan, H. Li, X. Tang, and C. Uher, J. Mater. Chem. A 1, 12657 (2013).

${ }^{34} \mathrm{M}$. Gu, X. Xia, X. Huang, S. Bai, X. Li, and L. Chen, J. Alloys Compd. 671, 238 (2016).

${ }^{35}$ D. K. Kim, H. Lee, D. Kim, and Y. Keun Kim, J. Cryst. Growth 283(3-4), 404 (2005).

${ }^{36}$ L. Liu, Y. Wang, and H. Gong, J. Appl. Phys. 90(1), 416 (2001).

${ }^{37}$ M. Stavrev, D. Fischer, and C. Wenzel, Thin Solid Films 307, 79 (1997).

${ }^{38}$ J. Nazon, B. Fraisse, J. Sarradin, S. G. Fries, J. C. Tedenac, and N. Fréty, Appl. Surf. Sci. 254, 5670 (2008).

${ }^{39}$ H. H. Hsu, C. H. Cheng, Y. L. Lin, S. H. Chiou, C. H. Huang, and C. P. Cheng, Appl. Phys. Lett. 103, 053902 (2013).

${ }^{40}$ H. H. Hsu, C. H. Cheng, S. H. Chiou, C. H. Huang, C. M. Liu, Y. L. Lin, W. H. Chao, P. H. Yang, C. Y. Chang, and C. P. Cheng, J. Alloys Compd. 588, 633 (2014).

${ }^{41}$ L. Boulat, R. Viennois, D. Ravot, and N. Fréty, MRS Online Proc. Libr. 1490, 197 (2013).
${ }^{42}$ L. Chapon, D. Ravot, and J. C. Tedenac, J. Alloys Compd. 282, 58 (1999).

${ }^{43}$ R. Viennois, L. Girard, D. Ravot, S. Paschen, S. Charar, A. Mauger, P. Haen, and J. C. Tedenac, Phys. Rev. B 80, 155109 (2009).

${ }^{44}$ J. Nazon, J. Sarradin, V. Flaud, J. C. Tedenac, and N. Fréty, J. Alloys Compd. 464, 526 (2008).

${ }^{45}$ A. Jara, B. Fraisse, V. Flaud, N. Fréty, and G. Gonzalez, Surf. Coat. Technol. 309, 887 (2017).

${ }^{46}$ B. A. Movchan and A. V. Demchishin, Phys. Met. Metallogr. 28, 83 (1969).

${ }^{47}$ J. A. Thornton, Ann. Rev. Mater. Sci. 7, 239 (1977).

${ }^{48}$ S. Tsukimoto, M. Moriyama, and M. Murakami, Thin Solid Films 460(1/2), 222 (2004).

${ }^{49}$ P. Scherrer, Nach. Ges. Wiss. Göttingen 2, 98 (1918).

${ }^{50}$ G. S. Nolas, D. T. Morelli, and T. M. Tritt, Annu. Rev. Mat. Sci. 29, 89 (1999).

${ }^{51}$ D. Zhao, C. Tian, Y. Liu, C. Zhan, and L. Chen, J. Alloys Compd. 509, 3166 (2011).

52J. Nazon, M. H. Berger, J. Sarradin, J. C. Tedenac, and N. Fréty, Plasma Process. Polym. 6, S844 (2009).

${ }^{53}$ W. L. Yang, W. F. Wu, D. G. Liu, C. C. Wu, and K. L. Ou, Solid-State Electron. 45, 149 (2001).

${ }^{54}$ N. Fréty, F. Bernard, J. Nazon, J. Sarradin, and J. C. Tedenac, J. Phase Equilib. Diff. 27, 590 (2006).

${ }^{55}$ S. Tsukimoto, M. Moriyama, and M. Murakami, Thin Solid Films 460, 222 (2004). 